\title{
POTENTIAL BIOMASS LIMITATIONS ON RATES OF DEGRADATION OF MONOAROMATIC HYDROCARBONS BY INDIGENOUS MICROBES IN SUBSURFACE SOILS
}

\author{
H. X. CORSEUIL ${ }^{\prime}$ and W. J. Weber $\mathrm{JR}^{2 *}$ \\ ${ }^{1}$ Departamento de Engenharia Sanitária, Universidade Federal de Santa Catarina, Florianópolis, \\ SC 88039, Brazil and 'Department of Civil and Environmental Engineering, The University of Michigan, \\ Ann Arbor, MI 48109, U.S.A.
}

(First received January 1993; accepted in revised form September 1993)

\begin{abstract}
The rates of biodegradation of benzene, toluene and xylene by indigenous microorganisms in a natural aquifer sand were investigated. Despite highly favorable nutrient and electron acceptor conditions, the onset of measurable microbial oxidation of these readily degraded compounds was observed to be delayed in systems containing small populations of microbes. The delays varied inversely with the initial number of microbes capable of degrading a particular compound, suggesting the need for development of some critical population of microorganisms. In terms of the onset of oxygen consumption, xylene involved the longest critical population development period, consistent with the low comparative numbers of indigenous microbes found capable of degrading this compound.
\end{abstract}

Key words--bioremediation, organic contamination, groundwater, soils, biodegradation, monoaromatic, hydrocarbon spills

\section{INTRODUCTION}

A wide variety of organic contaminants are known to be readily degraded biologically under laboratory conditions, suggesting broad-scale efficacy for use of biological processes to remediate contaminated subsurface systems. Much lower rates of biotransformation are commonly observed in field environments, however. In particular, significant delays are often noted before demonstrable degradation of newly introduced organic contaminants occurs. Factors reported to affect the length of such delays include enzyme induction, genetic changes and numbers of microbes capable of degrading target compounds (Spain et al., 1980; Spain and Van Veld, 1983; Wiggins et al., 1987; Aelion et al., 1987; Aamand et al., 1989; Spain, 1990).

Regardless of their specific causes, significant delays in the onset of measurable degradation must be considered in predictions of contaminant transport and fate in subsurface environments, and in estimates of bioremediation rates (Spain and Van Veld, 1983; Wiggins et al., 1987). No method currently exists for predicting the magnitude of delays between introduction of a contaminant and the onset of its measurable biodegradation (Alexander and Scow, 1989). This study investigates the biokinetics of aromatic hydrocarbon degradation and examines as-

*Author to whom all correspondence should be addressed. sociated delays in the onset of measurable substrate utilization in sandy aquifer materials under favorable growth conditions. It further explores the hypothesis that such delays may be attributable to insufficient numbers of "contaminant-adapted" indigenous microbes; specifically, to the need for such microbes to achieve a population sufficient to yield demonstrable contaminant degradation. Substrate utilizate rates are, after all, directly proportional to biomass. In this context apparent delays in the onset of measurable activity may in fact be the times required for critical populations to occur; i.e. critical population development (CPD) periods. While this seems an obvious point, it is one which is generally overlooked in laboratory assessments and field applications of bioremediation, which tend to focus primarily on electron acceptor and nutrient requirements and deficiencies.

The monoaromatic hydrocarbons benzene, toluene and xylene chosen for this investigation are common constituents of contaminated groundwaters. A series of batch and column experiments was developed. Biokinetic parameters and the effects of temperature on microbial growth were determined in batch experiments with microorganisms isolated from a non-contaminated aquifer material. The effects of substrate concentration and flow conditions on the active mass of indigenous microbes responsible for the degradation of the BTX compounds were then investigated in column experiments. The work was conducted to establish a firm scientific basis for determining 
whether biomass limitations need be considered in engineering applications of in situ biological processes for decontamination of subsurface systems.

\section{MATERIALS AND METHODS}

The sandy aquifer material used in this study was obtained from a natural gas production facility in Kalkaska, Mich., beneath which large plumes of benzene, toluene and xylene were detected in 1984 (Chiang et al., 1989). The material was collected by split-spoon sampling of bore SB-1, depth $3-7 \mathrm{ft}$, a non-contaminated area of the facility, and refrigerated at $6^{\circ} \mathrm{C}$. Analysis of the Kalkaska solids revealed a composition of $99.8 \%$ sand and $0.2 \%$ silt and clay, with an organic carbon content of $0.07 \%$ as determined by low temperature wet oxidation (McGinley, 1991).

A synthetic nutrient solution was used to provide environmental conditions favorable for the growth of indigenous microorganisms present in the aquifer sands tested. This solution was comprised by addition of: $0.2 \mathrm{~g}$ of $\mathrm{MgSO}_{4} \cdot 7 \mathrm{H}_{2} \mathrm{O}, 0.1 \mathrm{~g}$ of $\mathrm{CaCl}_{2}, 0.05 \mathrm{mg}$ of $\mathrm{FeSO}_{4} \cdot 7 \mathrm{H}_{2} \mathrm{O}$, $0.25 \mathrm{mg}$ of $\mathrm{NaMoO}_{4} \cdot 2 \mathrm{H}_{2} \mathrm{O}, 0.43 \mathrm{~g}$ of $\mathrm{K}_{2} \mathrm{HPO}, 0.23 \mathrm{~g}$ of $\mathrm{KH}_{2} \mathrm{PO}_{4}$ and $0.05 \mathrm{~g}$ of $\mathrm{KNO}_{3}$, to 1 liter of Milli-Q water. Nitrate was employed as the nitrogen source to limit growth of nitrifiers, which by increasing oxygen demand might limit the availability of electron acceptors for target compound degradation.

The monoaromatic compounds used were analyzed either by gas chromatography preceded by separation in a purgeand-trap device (Environchem model 810A, Environchem Inc., Kemblesville, $\mathrm{Pa}$ ) or by head-space analysis [on an HP 5890 GC equipped with a head space analyzer model HP 19395A (Hewlett-Packard, Avondale, Pa)]. A 5\% SP $6^{\prime} \times 1 / 4^{\prime \prime} \times 2 \mathrm{~mm} 1200 / 1.75 \%$ Benton 34, Supelcoport, $100 / 200$ mesh \#707810 column was used in the purge-andtrap and an HP-5 Crosslinked $5 \% \mathrm{Ph}$ Me Silicone, $30 \mathrm{~m} \times 0.53 \mathrm{~mm} \times 2.6 \mathrm{~mm}$ thickness in the head-space analysis. Helium was used as the carrier gas. The target compounds were separated isothermally at $75^{\circ} \mathrm{C}$ and detected by flame ionization. External standards were prepared routinely to check against standard calibration curves. Detection limits for the instruments employed were $0.1 \mathrm{ppb}$ (with a $10-\mathrm{ml}$ volume sample) and $10 \mathrm{ppb}$, respectively, for the purge-and-trap and head-space analyses. Dissolved oxygen was measured using an oxygen meter (YSI model 5300 Biological Oxygen Monitor, Yellow Spring, Ohio) equipped with a micro flow-through system. The equipment was able to detect dissolved oxygen levels as low as $0.1 \mathrm{mg} / \mathrm{l}$.

The numbers of microorganisms present in solution were quantified by standard plate count. Dilutions were made in a potassium phosphate buffer containing $0.5 \mathrm{mg} / 1$ of Tween 80 (ICN Nutritional Biochemicals, Irvine, Calif.) as an anticlumping agent (Chang and Rittmann, 1988). Appropriate dilutions were applied to $0.5 \%$ tryptone nutrient (Difco Laboratories, Detroit, Mich.), agar (BBL Microbiology Systems, Cockeysville, Md), plates according to Standard Methods (APHA, 1989). Plates were cultured at $30^{\circ} \mathrm{C}$ and colonies were counted after 3 days. The use of this medium, which allows estimates only of the total number of heterotrophs, was deemed appropriate in this study because experiments were performed in the presence of only one hydrocarbon at a time, and no additional carbon sources were provided. A plate count technique using benzene, toluene and xylene vapors was also tested, but discarded because of the long period ( 2 weeks) required for obtaining colonies large enough to be counted. Enumeration of bacteria attached to sand was done by shaking $10 \mathrm{~g}$ of sand in $100 \mathrm{ml}$ of a sterile $0.1 \%$-sodium pyrophosphate solution for $20 \mathrm{~min}$ (Wilson et al, 1983). The microorganisms released by this technique were then quantified by the standard plate count method.

\section{Determination of biokinetic parameters}

Four biokinetic coefficients were determined independently for benzene, toluene and $o$-xylene: (i) the maximum specific substrate utilization rate (MSSUR) coefficient, $k$, (ii) the half-velocity coefficient, $K_{\mathrm{s}}$; (iii) the yield coefficient, $Y$; and (iv) the cell decay coefficient $b$. These coefficients were determined using microorganisms obtained from columns of Kalkaska sand which had been previously fed on a continuous basis with an aqueous solution of approx. $2 \mathrm{mg} / 1$ of benzene, toluene or $o$-xylene as the sole carbon source for 10 days, or until the contaminants had been completed degraded, whichever occurred first. Rate studies were performed in batch systems using a replicated series of $5-\mathrm{ml}$ screw-cap glass vials sealed with Teflon-coated septa. Samples of effluent from each reactor containing adapted microorganisms were collected and homogenized, and a $100-\mu 1$ aliquot then added to the $5-\mathrm{ml}$ vials, each of which served as a separate reactor for generation of a single point for the subsequent biodegradation rate analyses. This minimized propagation of experimental error from one data point to another. The designated solutions of target compound, the sole carbon source, were prepared in head-spacefree glass cylinders and then added with a gas-tight syringe to the vials, which were immediately sealed. Vials without microorganisms and containing $100 \mathrm{mg} / \mathrm{l}$ azide were also prepared for controls. Two vials were promptly analyzed for determination of initial contaminant and biomass concentrations. Periodic analyses of the hydrocarbons were then performed. Parameters were estimated using non-linear regression analysis performed with the Systat 5.1 application software (Systat Inc.)

\section{Sand column systems}

The sand columns consisted of packed $2.54-\mathrm{cm}$ i.d. glass cylindrical reactors operated in upflow mode. Once packed, each system was washed with $200 \mathrm{ml}$ of autoclaved synthetic groundwater to remove air bubbles. A 50-g charge of sand was used in each experiment, packed to a depth of approx. $6.1 \mathrm{~cm}$. Tracer experiments with sodium chloride showed that the sand columns were well packed, and that flow conditions closely approximated those of an ideal plug-flow reactor. Aqueous solutions containing the desired concentrations of target compounds were prepared in a headspace-free glass cylinder, as previously described, and delivered to the reactors by a Miniplus 2 peristaltic pump (Gilson Medical Electronics, S.A., France). All tubing was of viton or stainless steel to minimize adsorption onto tubing surfaces. Materials were autoclaved prior to use, and samples were collected with gas-tight syringes and analyzed immediately to prevent losses by biodegradation or volatilization. Experiments were done at room temperature $\left(22^{\circ} \mathrm{C}\right)$ unless otherwise specified, and at interstitial velocities ranging from 0.2 to $2 \mathrm{~m} / \mathrm{day}$, which provided hydraulic detention times of approx. $7.5 \mathrm{~h}$ and $45 \mathrm{~min}$, respectively. Column experiments in which microbial activity was prevented by the addition of sodium azide were performed to confirm that sorption of the target compounds by the low organic content $(0.07 \%)$ Kalkaska sands, was, as expected, modest, completely reversible and insignificant as a removal mechanism. These experiments also served as controls for studies of degradation under continuous flow conditions. No losses that could be attributed to volatilization or to improper sampling of the target compounds were observed.

\section{RESULTS AND DISCUSSION}

\section{Biokinetic parameters}

Models describing biological growth and substrate utilization are usually based on Monod kinetics. Rate relationships for substrate utilization and net microbial growth in batch reactors have been given by: 


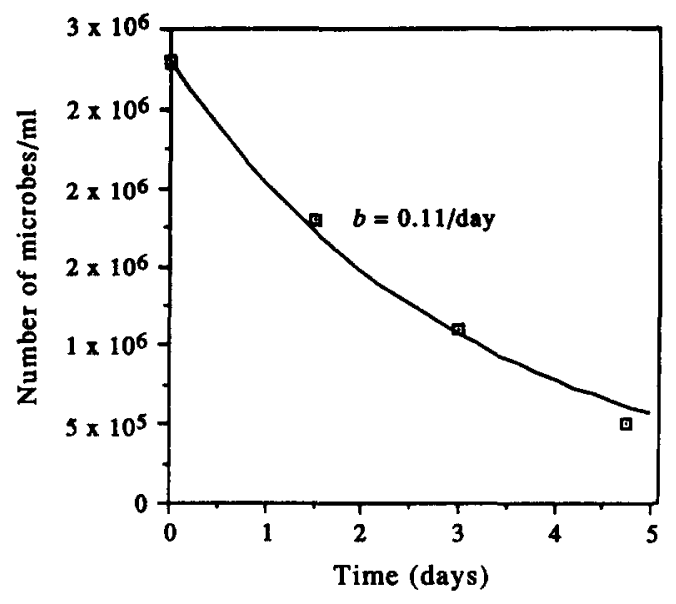

Fig. I. Batch experimental data and model simulation for determination of the decay coefficient for xylene.

$$
-\frac{\mathrm{d} S}{\mathrm{~d} t}=\frac{k X S}{K_{\mathrm{s}}+S}
$$

and,

$$
\frac{\mathrm{d} X}{\mathrm{~d} t}=\frac{Y k S X}{K_{\mathrm{s}}+S}-b X
$$

where $S$ is the substrate concentration $(\mathrm{mg} / \mathrm{l}) ; t$ is time; $X$ is the microbial concentration $(\mathrm{mg} / \mathrm{l})$; and, $k$ [mg-substrate (mg-cells)/day], $K_{\mathrm{s}}(\mathrm{mg} / \mathrm{l}), Y$ (mg cells/ $\mathrm{mg}$ substrate) and $b\left(\right.$ day $\left.^{-1}\right)$ are as previously defined. Equation (2) is based on the assumption that microbial growth manifests a hyperbolic profile.

A relationship between free energies of reaction and maximum cell yields based on classical thermodynamics was demonstrated by McCarty (1975) to be valid for heterotrophic and autotrophic bacteria. This model was used to determine values for the yield coefficients, $Y$, which, based on overall stoichiometry, were $0.65,0.66$ and 0.67 for benzene, toluene and xylene, respectively. Details of the calculations have been provided elsewhere (Corseuil, 1992).

To determine the decay coefficient, $b$, samples of effluent were collected from a sand column which had been fed with $o$-xylene for more than 10 days; that is, until complete degradation of the hydrocarbon occurred. Several 5-ml vials were filled with the sample and plate count analyses were performed over time. This procedure was performed twice, once over a period of 5 days and once for 13 days. Experimental results and a simulation using a first-order decay model are presented in Fig. 1 for the 5-day experiment. Parameter values for nonlinear regression fits of the 5- and 13-day experimental data are presented in Table 1. A value of $b=0.11 /$ day, which is inside the $95 \%$ confidence interval for both experiments and in the range normally cited for other organic compounds, was used for the xylene degraders. For subsequent model simulations, the decay coefficients for benzene and toluene were assumed to be the same as that for xylene.

Values for the maximum specific substrate utilization rate, $k$, and the half-velocity coefficient, $K_{\mathrm{s}}$, were determined from independent batch experiments using non-linear regression analyses to obtain unique parameter estimates. The coefficient $k$ was determined from experiments at high substrate concentration, for which it was assumed that the initial substrate concentration, $S_{0}$, was much higher than $K_{\mathrm{s}}$. Initial concentrations of BTX compounds were maintained at levels below $4 \mathrm{mg} / 1$ to avoid potential oxygen limitations. When $K_{\mathrm{s}}$ is much smaller than the initial substrate concentration, the rate of substrate utilization is zero-order with respect to $S$. For this case, it is easy to obtain the simultaneous solution of equations (1) and (2), which yields the following model for zero-order substrate utilization with microbial growth:

$$
S=S_{0}-\frac{k}{(Y k-b)} X_{0}\left[\mathrm{e}^{(Y k-b) t}-1\right]
$$

Experiments with low initial substrate concentration were used to determine the half-velocity coefficient. According to Monod kinetics, substrate utilization rate is much more dependent on the half-velocity coefficient at low substrate concentrations than it is at high concentrations. A solution of the integrated form of equation (1), in which the assumption that $X=Y\left(S_{0}-S\right)+X_{0}$ (relating $X$ at time $t$ to $S$ ) was used to eliminate the biomass variable, was presented by Robinson and Tiedje (1983):

$$
\begin{aligned}
C_{1} \ln \left\{\left[Y\left(S_{0}-S\right)+X_{0}\right] / X_{0}\right\} & \\
& -C_{2} \ln \left(S / S_{0}\right)=\mu_{\text {max }} t
\end{aligned}
$$

where

$$
\begin{aligned}
& C_{1}=\left(K_{\mathrm{s}} Y+S_{0} Y+X_{0}\right) /\left(Y S_{0}+X_{0}\right) \\
& C_{2}=\left(K_{\mathrm{s}} Y /\left(Y S_{0}+X_{0}\right)\right.
\end{aligned}
$$

$X_{0}$ is the initial biomass; $S_{0}$ is the initial substrate concentration; and $\mu_{\max }=k Y$, the maximum specific

\begin{tabular}{|c|c|c|c|c|}
\hline $\begin{array}{l}\text { Period of } \\
\text { observation }\end{array}$ & $\begin{array}{c}\text { Decay } \\
\text { coefficient } b \\
\left(\text { day }^{-1}\right)\end{array}$ & $\begin{array}{l}95 \% \text { Confidence } \\
\text { interval }\end{array}$ & $\begin{array}{c}\text { Asymptotic } \\
\text { standard error }\end{array}$ & $\begin{array}{c}\text { Correlation } \\
\text { coefficient }\end{array}$ \\
\hline 5 days & 0.14 & $0.11-0.16$ & 0.007 & 0.995 \\
\hline 13 days & 0.11 & $0.09-0.12$ & 0.005 & 0.992 \\
\hline
\end{tabular}
growth rate. Equation (4) was used in the non-linear regression analysis to estimate $K_{\mathrm{s}}$. Biomass concentration was converted from cell numbers assuming a microbial cell with a dry weight of $2 \times 10^{-10} \mathrm{mg}$ (McCarty, 1985).

Table 1. Decay coefficients for $o$-xylene in CMBRs 


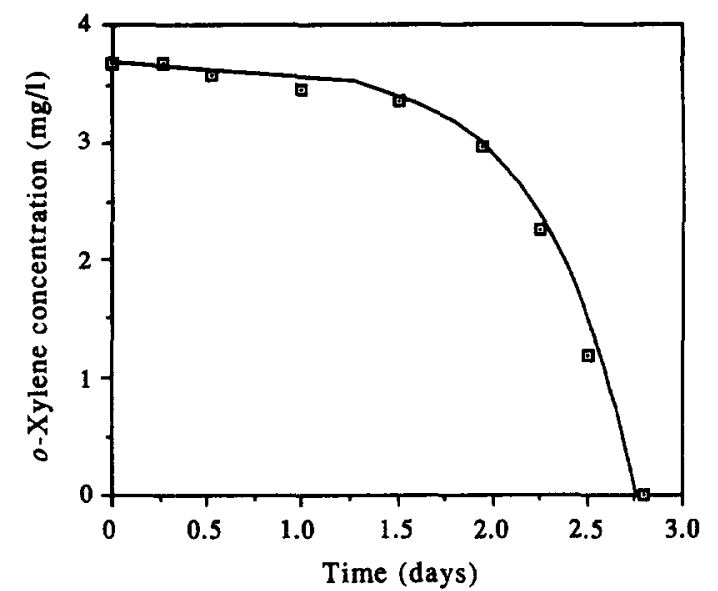

Fig. 2. CMBR data and model simulation for biodegradation of $o$-xylene $\left(S_{0}=3.70 \mathrm{mg} / 1\right.$ and $X_{0}=5 \times 10^{4}$ cells $\left./ \mathrm{ml}\right)$.

Xylene, which was observed to be the most persistent contaminant at the Kalkaska production site, was the first to be studied. The data in Figs 2 and 3 for high initial xylene concentrations reveal an approx. $40-45 \%$ difference in the lag periods before onset of significant degradation at the two different biomass levels. Complete degradation of the $3.7 \mathrm{mg} / \mathrm{l}$ of xylene at the higher biomass level required only 2.75 days, while the lower biomass system required 3.75 days for degradation of $2.15 \mathrm{mg} / 1$ of xylene. The resulting overall conversion rate at the higher biomass level, $1.35 \mathrm{mg} / \mathrm{l}$-day, was thus approx. 2.4 times the conversion rate of $0.57 \mathrm{mg} / \mathrm{l}$-day at the lower biomass level.

Parameter values for non-linear regression fits of the data presented in Figs 2 and 3 are given in Table 2 , along with parameter values for two separate experiments performed with $o$-xylene concentrations in the range of $20 \mu \mathrm{g} / 1$ and different initial biomass concentrations. These latter two experiments were used for estimation of $K_{\mathrm{s}}$, as presented in Table 3. An MSSUR coefficient of $k=3.11 /$ day (Table 2) was used for the non-linear regression fit. The small values of $K_{\mathrm{s}}$ obtained indicates that this parameter could probably have been neglected in the model [equation (4)] calculations without having any real effect on the simulations. The numbers in Table 3 also indicate that, for this particular case, $K_{\mathrm{s}}$ cannot be accurately estimated from experiments at initial substrate concentration in the range of $20 \mu \mathrm{g} / \mathrm{l}$. These

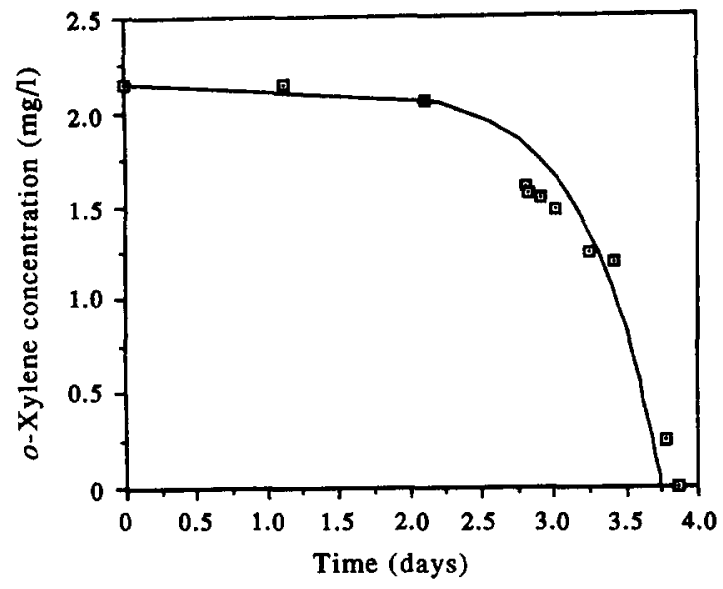

Fig. 3. CMBR data and model simulation for biodegradation of $o$-xylene $\left(S_{0}=2.15 \mathrm{mg} / 1\right.$ and $X_{0}=3 \times 10^{3}$ cells $\left./ \mathrm{ml}\right)$.

results validate the assumption of zero-order kinetics with respect to substrate $\left(S_{0} \gg K_{\mathrm{s}}\right)$ for the experiments at high xylene concentration. New simulations were performed using the zero-order model, equation (3), and the low concentration data to estimate the maximum specific utilization rate. As illustrated in Table 2, the estimated $k$ values for the low xylene concentrations are, for all practical purposes, within the $95 \%$ confidence interval of the simulations for high $o$-xylene concentrations.

Experiments similar to the ones described above for $o$-xylene were performed also for benzene and toluene. Figure 4 shows data and zero-order model simulations for benzene at high initial substrate concentration. The same value for the maximum specific substrate utilization rate, $k$, was obtained at high and low benzene concentrations, an indication that $K_{\mathrm{s}}$ is small compared to $22 \mu \mathrm{g} / 1$ (Table 2). For the conditions tested, these results show that the half-velocity coefficient $\left(K_{\mathrm{s}}\right)$ can be neglected for concentrations above $\sim 20 \mu \mathrm{g} / \mathrm{l}$. Experimental data and the model simulation for determination of the $k$ value for toluene are presented in Fig. 5. In this simulation initial substrate and biomass concentrations, $S_{0}$ and $X_{0}$, were $1.44 \mathrm{mg} / \mathrm{l}$ and $0.10 \mu \mathrm{g} / 1\left(5 \times 10^{2}\right.$ cells $\left./ \mathrm{ml}\right)$, respectively. The estimated value of $k$ was 2.73 day $^{-1}$, with a $95 \%$ confidence interval of $2.72-2.75 \mathrm{day}^{-1}$. Controls with sodium azide showed losses of less than $5 \%$ for all batch experiments. A summary of the

Table 2. Maximum specific substrate utilization rate coefficients for $o-x y l e n e$ and benzene in CMBRs

\begin{tabular}{|c|c|c|c|c|c|}
\hline $\begin{array}{l}\text { Initial substrate } \\
\text { concentration } \\
S_{0}(\mu \mathrm{g} / 1)\end{array}$ & $\begin{array}{c}\text { Initial biomass } \\
\text { concentration } \\
X_{0}(\mu \mathrm{g} / 1)\end{array}$ & $\begin{array}{c}\text { MSSUR } \\
\text { coefficient } \\
k\left(\text { day }^{-1}\right) \\
\end{array}$ & $\begin{array}{c}95 \% \text { Confidence } \\
\text { interval }\end{array}$ & $\begin{array}{c}\text { Asymptotic } \\
\text { standard error }\end{array}$ & $\begin{array}{c}\text { Correlation } \\
\text { coefficient }\end{array}$ \\
\hline \multicolumn{6}{|l|}{ o-Xylene } \\
\hline 20.5 & 0.08 & 3.03 & $2.93-3.13$ & 0.042 & 0.987 \\
\hline 22.0 & 0.60 & 3.06 & $2.99-3.14$ & 0.036 & 0.992 \\
\hline 3700 & 10.00 & 3.11 & $3.06-3.15$ & 0.020 & 0.997 \\
\hline 2150 & 0.60 & 3.18 & $3.13-3.23$ & 0.023 & 0.986 \\
\hline \multicolumn{6}{|l|}{ Benzene } \\
\hline 1440 & 3.50 & 2.58 & $2.49-2.66$ & 0.025 & 0.993 \\
\hline 2200 & 0.80 & 2.59 & $2.49-2.68$ & 0.030 & 0.994 \\
\hline
\end{tabular}


Table 3. Half-velocity coefficients for low substrate levels of $o$-xylene in CMBRs

\begin{tabular}{lccccc}
\hline $\begin{array}{l}\text { Initial substrate } \\
\text { concentration }\end{array}$ & $\begin{array}{c}\text { Initial biomass } \\
\text { concentration } \\
X_{0}(\mu \mathrm{g} / 1)\end{array}$ & $\begin{array}{c}\text { Half-velocity } \\
\text { coefficient } \\
K_{\mathrm{s}}(\mu \mathrm{g} /)\end{array}$ & $\begin{array}{c}95 \% \text { Confidence } \\
\text { interval }\end{array}$ & $\begin{array}{c}\text { Asymptotic } \\
\text { standard error }\end{array}$ & $\begin{array}{c}\text { Correlation } \\
\text { coefficient }\end{array}$ \\
\hline 20.5 & 0.08 & 0.7 & $0.1-2.4$ & 0.0008 & 0.977 \\
22.0 & 0.60 & 0.1 & $-2.0-1.1$ & 0.001 & 0.984 \\
\hline
\end{tabular}

biokinetic parameters obtained for benzene, toluene and $o$-xylene using the zero-order model with microbial growth is presented in Table 4 .

\section{Temperature effects}

Temperature is a critical environmental factor with respect to rates of microbial degradation. The average groundwater temperature at the Kalkaska site is below $10^{\circ} \mathrm{C}$ (Chiang et al., 1989). Batch experiments were performed with $o$-xylene degraders at three different temperatures to determine the effects of this parameter on maximum substrate utilization rates. Non-linear regression was used to fit the data to estimate $k$ for each temperature. Data and zero-order model simulations for $o$-xylene disappearance at 8,22 and $29^{\circ} \mathrm{C}$ are presented in Fig. 6, and statistical results in Table 5. Variations in reaction rate as a function of temperature may be described by the Arrhenius equation. The rate constants for each temperature were then plotted vs $1 / T(K)$ to determine the activation energy, as illustrated in Fig. 7. From these data it was determined that the activation energy had a value of $E_{\mathrm{a}}=16.4 \mathrm{kcal} / \mathrm{mol}$ with a $95 \%$ C.I. of $\pm 0.13 \mathrm{kcal} / \mathrm{mol}$. Because temperatures in natural waters vary over relatively narrow ranges, the Arrhenius equation can be simplified, and the term $E_{\mathrm{a}} / R T_{1} T_{2}$ replaced by a temperature coefficient $\theta$ The maximum substrate utilization rate for $o$-xylene can then be adjusted for temperature effects using the following simplified equation:

$$
\frac{k_{1}}{k_{2}}=1.104^{\left(T_{1}-T_{2}\right)}
$$

Although rates of enzymatically catalyzed reactions

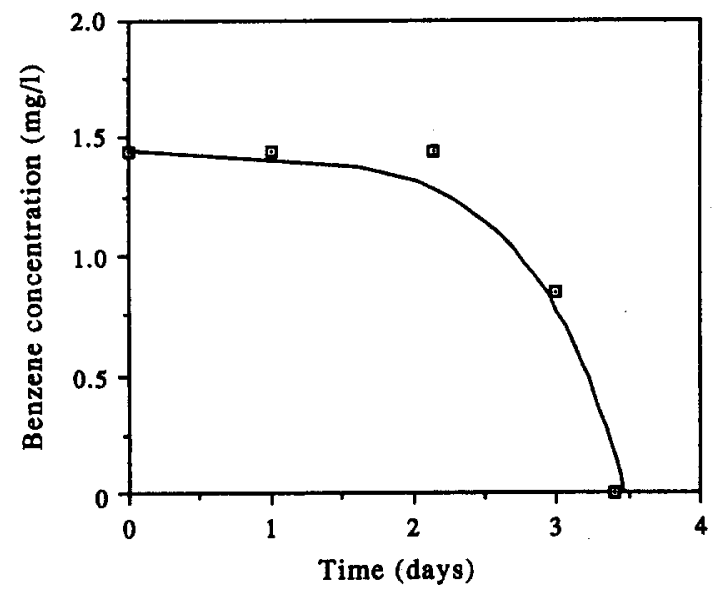

Fig. 4. CMBR data and model simulation for biodegradation of benzene $\left(S_{0}=1.44 \mathrm{mg} / \mathrm{l}\right.$ and $X_{0}=7 \times 10^{3}$ cells $\left./ \mathrm{ml}\right)$. are usually considered to decrease by a factor of two with every $10^{\circ} \mathrm{C}$ decrease in temperature (Atlas and Bartha, 1987), equation (5) predicts that the maximum substrate utilization rate for $o$-xylene will decrease by a factor of three for a $10^{\circ} \mathrm{C}$ decrease in temperature. Similar behavior can probably be assumed for the other compounds studied, benzene and toluene.

\section{Column experiments}

Experiments at high initial concentration were performed first for benzene, toluene and $o+p$-xylene to examine lag effects and biodegradation rates by the indigenous Kalkaska microorganisms under continuous flow and oxygen-limited conditions. Studies were done at ambient temperature and an interstitial velocity of $2.0 \mathrm{~m} /$ day. Individual target compounds were added as single carbon sources at influent concentrations of approx. 8-9 mg/l (approx. $4.5 \mathrm{mg} / \mathrm{l}$ of each of the two isomers in the case of xylene). Dissolved oxygen concentration in the synthetic solution fed to the columns was maintained at values between 7.0 and $8.0 \mathrm{mg} / \mathrm{l}$.

Breakthrough curves for benzene, toluene and $o+p$-xylene and the percentage of oxygen utilized by the indigenous microbial populations in columns of Kalkaska sand varied proportionally over time, illustrating, as indicated in Figs 8-10, the direct connection between target compound consumption and oxygen utilization. In all cases, biodegradation ultimately reached a limit due to complete consumption of oxygen, resulting in a rough leveling of effluent concentrations after approx. 12 days for benzene and 5 days for toluene and xylene. The initiation of

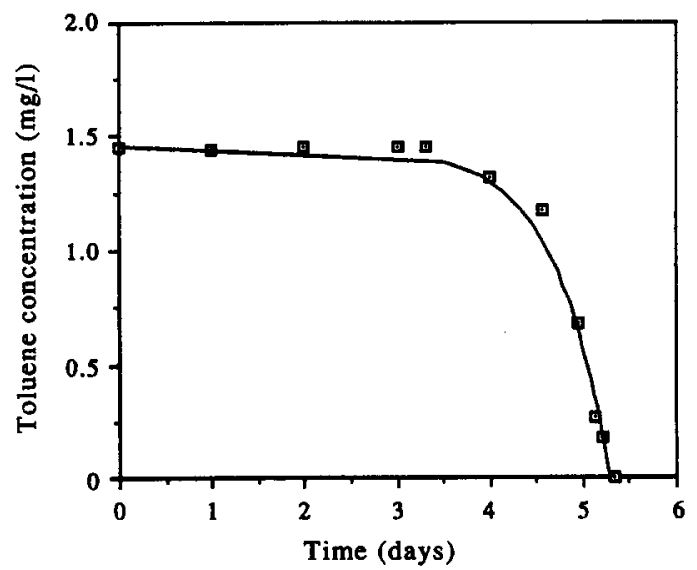

Fig. 5. CMBR data and model simulation for biodegradation of toluene $\left(S_{0}=1.45 \mathrm{mg} / \mathrm{l}\right.$ and $X_{0}=5 \times 10^{2}$ cells $\left./ \mathrm{ml}\right)$. 
Table 4. Biokinetic parameters for BTX compounds--Kalkaska sand

\begin{tabular}{lcccc}
\hline Compound & $k\left(\right.$ day $\left.^{-1}\right)$ & $\begin{array}{c}95 \% \text { Confidence } \\
\text { interval }\end{array}$ & $Y$ & $b\left(\text { day }^{-1}\right)^{*}$ \\
\hline Benzene & 2.58 & $2.49-2.66$ & 0.65 & - \\
Toluene & 2.73 & $2.72-2.75$ & 0.66 & - \\
$o$-Xylene & 3.11 & $3.06-3.15$ & 0.67 & 0.11 \\
\hline
\end{tabular}

*The same value was used in simulations for benzene and toluene.

biodegradation in these three column experiments, as measured by $\mathrm{O}_{2}$ consumption, occurred immediately for benzene, followed by toluene at 1 day and xylene at approx. 3 days. An inverted order was observed with respect to time required for maximum oxygen utilization, however. After a longer delay in the onset of oxygen use, xylene degraders more rapidly achieved consumption of all available oxygen than did the toluene and benzene degraders. This accords with the results of the batch biokinetic studies presented earlier.

Plate count analyses on the column effluents revealed different types of dominant bacteria for the three monoaromatic hydrocarbons under oxygenlimiting conditions. The population of the predominant microorganisms was approximately one order of magnitude larger than those of the other two or three types of bacteria present in each case. Plate counts of the indigenous microbial populations attached to the original non-contaminated aquifer sand were done using extractions with sodium pyrophosphate to determine the initial numbers of microorganisms capable of degrading each compound. Although it is impossible to determine exactly the initial number of specific contaminant degraders present in aquifer solids, these analyses revealed that xylene degraders were present in a much lower number $\left(\sim 10^{3}\right.$ cells $/ \mathrm{g}$ of dry solids) than the benzene and toluene degraders ( $\sim 10^{4}$ cells/g of dry solids). The total number of heterotrophs present in the original sand was in the order of $10^{4}-10^{5} / \mathrm{g}$ of dry solids.

Sand column experiments under continuous flow conditions were performed with benzene and $o$ xylene to study lag effects in the presence of trace levels of hydrocarbons. The influence of interstitial velocity was also evaluated in these experiments, and found to have a major impact on benzene degradation. Results at an influent concentration of $25 \mu \mathrm{g} / 1$ and an interstitial velocity of $2.0 \mathrm{~m} /$ day showed complete removal of benzene across the column after 12 days. Plate counts at the end of the experiment revealed that the microbial population attached to the soil increased approximately two orders of magnitude (from $10^{4}$ to $10^{6}$ cells/g of dry solids) over this

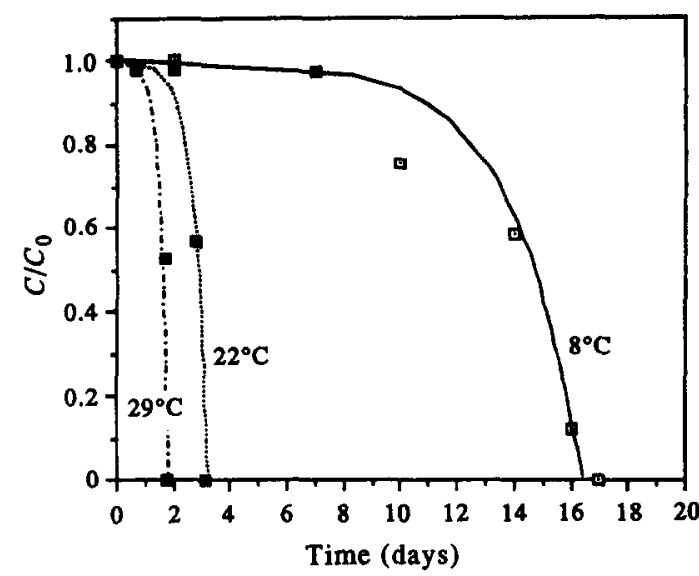

Fig. 6. CMBR data and model simulation for biodegradation of $o$-xylene at different temperatures.

period. The same study was repeated for an interstitial velocity of $0.22 \mathrm{~m} /$ day, for which less than $2 \mu \mathrm{g} / \mathrm{l}$ appeared in the column effluent in the first $10 \mathrm{~h}$, and for which benzene was no longer detected at an analytical limit of $0.1 \mu \mathrm{g} / \mathrm{l}$ after $30 \mathrm{~h}$. One explanation for the observed effect of interstitial velocity, which of course has an associated loading effect, relates to the initial number of benzene degraders present in the Kalkaska sand; that is, the indigenous microorganisms may have been present in sufficient numbers to metabolize the $1.2 \mu \mathrm{g}$ benzene mass added per day at the low velocity but not the $11.1 \mu \mathrm{g} /$ day mass added at the higher velocity.

As indicated in Fig. 11, the same phenomenon was observed with $o$-xylene as sole carbon source at an influent concentration of $25 \mu \mathrm{g} / 1$ and interstitial velocity of $0.22,0.67$ and $2.0 \mathrm{~m} / \mathrm{day}$. The indigenous microorganisms were able to degrade $o$-xylene below $0.1 \mu \mathrm{g} / \mathrm{l}$. Plate count analyses at the end of the experiments indicated that microorganisms released from the sand increased from $10^{4}$ to approx. 5 to $7 \times 10^{5} / \mathrm{g}$ of dry solids. Complete $o-x y l e n e$ disappearance occurred after between 5 and 7 days for the three velocities studied, but such complete disappearance took longer at an interstitial velocity of $0.22 \mathrm{~m} / \mathrm{day}$, the estimated groundwater velocity at the Kalkaska site, than it did at $0.67 \mathrm{~m} /$ day. Reasons for these observations may relate to the effects of increased liquid-film mass transfer resistance at low velocity.

The fact that interstitial velocity was not as significant for xylene as it was for benzene may be attributed to the lower initial number of xylene degraders present in the aquifer sand; i.e. approx. $10^{3}$ cells/g of dry solids. It is likely that this low microbial

Table 5. Temperature effects on the maximum specific substrate utilization rate for $o$-xylene in CMBRs

\begin{tabular}{lcccccc}
\hline $\begin{array}{l}\text { Temperature } \\
\text { ("C) }\end{array}$ & $\begin{array}{c}\text { Initial substrate } \\
\text { concentration } \\
S_{0}(\mathrm{mg} / \mathrm{l})\end{array}$ & $\begin{array}{c}\text { Initial biomass } \\
\text { concentration } \\
X_{0}(\mathrm{mg} / \mathrm{l})\end{array}$ & $\begin{array}{c}\text { MSSUR } \\
\text { coefficient } \\
k\left(\text { day }^{-1}\right)\end{array}$ & $\begin{array}{c}\text { Asymptotic } \\
\text { standard error }\end{array}$ & $\begin{array}{c}95 \% \text { Confidence } \\
\text { interval }\end{array}$ & $\begin{array}{c}\text { Correlation } \\
\text { coefficient }\end{array}$ \\
\hline 8 & 2.81 & 4.0 & 0.69 & 0.006 & $0.67-0.70$ & 0.987 \\
22 & 2.25 & 4.0 & 2.97 & 0.040 & $2.84-3.09$ & 0.997 \\
29 & 2.25 & 4.0 & 4.97 & 0.090 & $4.67-5.24$ & 0.982 \\
\hline
\end{tabular}




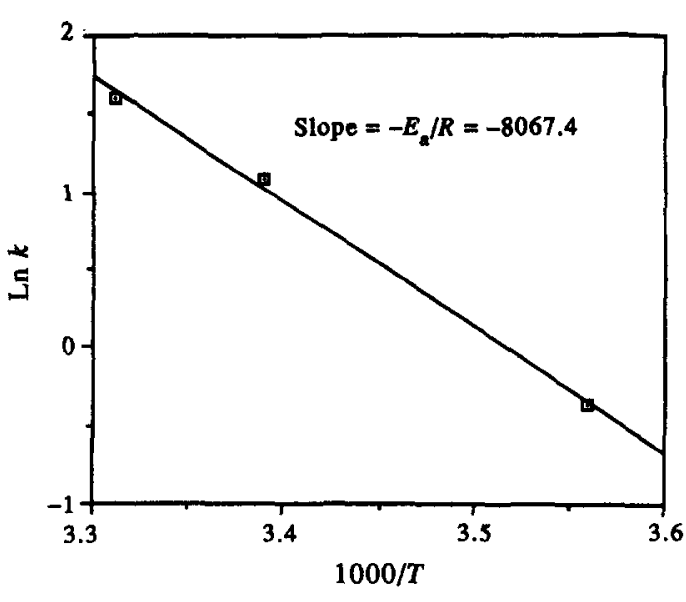

Fig. 7. Temperature effects on maximum specific substrate utilization rates for $o$-xylene.

density was not sufficient to effect the onset of measurable degradation as early as in the lowvelocity benzene experiment, for which the initial biomass was on the order of $10^{4}$ cells/g of dry solids.

Groundwater temperatures can significantly affect microbial growth rates and the times required for bioremediation even if all other microbial requirements (e.g. oxygen and nutrients) are satisfied. To test temperature effects under continuous flow, an experiment was performed using velocity and temperature conditions similar to those observed at the Kalkaska site $\left(0.22 \mathrm{~m} /\right.$ day and $\left.8^{\circ} \mathrm{C}\right)$. A column of the Kalkaska sand was fed with a mixed solution containing benzene, toluene and $o$-xylene (the only experiment with a mixed solution), each at a concentration of approx. $0.6 \mathrm{mg} / \mathrm{l}$. Low concentrations were chosen to prevent oxygen limiting conditions in order to observe the effects of temperature alone on rates of disappearance of the compounds. Under those conditions, total disappearance of benzene and toluene occurred after 16 days, and $o$-xylene after 24 days, as shown in Fig. 12. A simple completely mixed batch reactor (CMBR) model incorporating zero-order contaminant degradation with microbial growth as defined by equation (3) was used to predict BTX disappearance

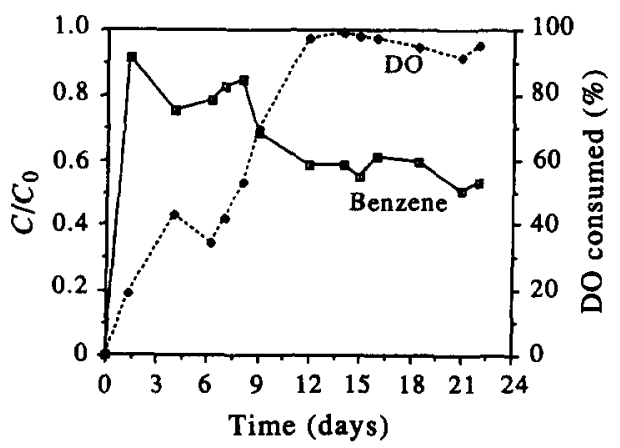

Fig. 8. Benzene breakthrough $\left(C_{0}=8.9 \mathrm{mg} / \mathrm{l}\right)$ and dissolved oxygen consumption patterns.

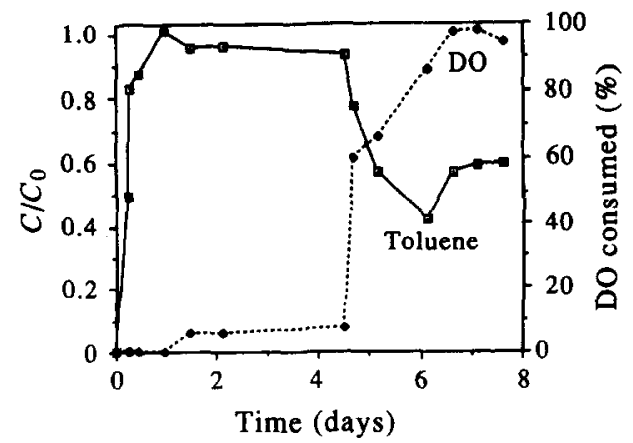

Fig. 9. Toluene breakthrough $\left(C_{0}=8.13 \mathrm{mg} / \mathrm{l}\right)$ and dissolved oxygen consumption patterns.

rates under the same flow and temperature conditions observed at the Kalkaska site, and at optimal nutrient and electron acceptor conditions. Equation (5) was used to adjust the maximum substrate utilization rates $(k)$ for the target compound to $8^{\circ} \mathrm{C}$. The estimated initial number of benzene and toluene degraders was $1.26 \mu \mathrm{g} / 1\left(10^{4} / \mathrm{g}\right)$, and xylene degraders was $0.125 \mu \mathrm{g} / 1\left(10^{3} / \mathrm{g}\right)$. Using the yield and decay coefficients shown in Table 4 and the zero-order model, benzene and toluene are predicted to disappear in 15 days, and xylene in 20 days. These are reasonable projections of the times obtained experimentally. As a point of interest, the order of disappearance observed in the laboratory experiments accords with observations at the Kalkaska site. Four years after the contaminants were first detected at that site, the planer area of contamination covered by the $10 \mu \mathrm{g} / 1$ plumes for benzene and toluene was $\sim 45 \times 30 \mathrm{~m}$, while the edge of the $10 \mu \mathrm{g} / 1$ xylene plume was distributed over an area of $\sim 300 \times 100 \mathrm{~m}$.

The critical population development periods of 2 weeks or so found is this study for $o$-xylene, or even those of 6 weeks reported for $p$-nitrophenol by Aelion et al. (1987), are small relative to those likely to be involved under typical field conditions, where subsurface heterogeneities and complexities render rates of microbial growth and contaminant degradation much less favorable (Alexander and Scow, 1989; Chiang et al., 1989; Downey and Elliot, 1990). The half-velocity coefficient $\left(K_{\mathrm{s}}\right)$ values measured in

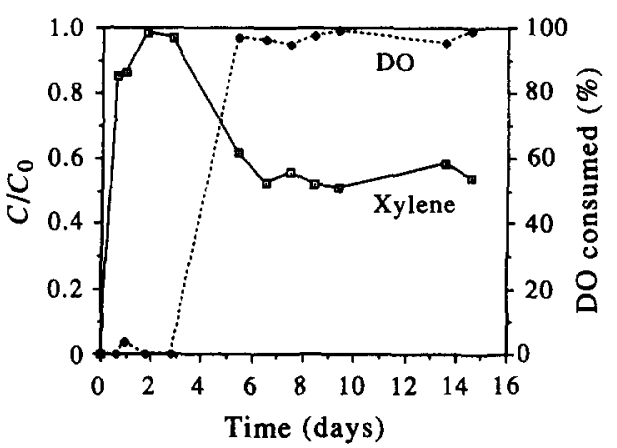

Fig. 10. $o+p-X y l e n e$ breakthrough $\left(C_{0}=9.11 \mathrm{mg} / 1\right)$ and dissolved oxygen consumption patterns. 
the laboratory tests were low, generally agreeing with those reported by Robertson and Button (1987) for toluene degradation by indigenous seawater microorganisms. Such low $K_{\mathrm{s}}$ values may not be representative of subsurface field conditions, however. The laboratory experiments were carefully designed and controlled to facilitate contact between contaminants, nutrients and microbes. Conditions of heterogeneity in the field will function to reduce intimate contact between substrate and microorganisms, contributing to higher $K_{\mathrm{s}}$ values for subsurface systems, as confirmed by Focht and Shelton (1987).

To gain some perspective of how the population development periods observed in the laboratory might translate to bioremediation practice, a modeling estimate was made of the time required for disappearance of xylene in a reasonably typical contaminated field situation. Equation (4) was employed to make calculations based on parameters determined in this study for the Kalkaska sand $\left(X_{0}=0.125 \mu \mathrm{g} / \mathrm{l}\right.$, $k=0.69 \mathrm{day}^{-1}, \quad Y=0.67, \quad b=0.11 \mathrm{day}^{-1}$ and $\left.T=8^{\circ} \mathrm{C}\right)$. A half-velocity coefficient of $\left(K_{\mathrm{s}}\right)=10 \mathrm{mg} / 1$ suggested by McCarty (1985) was employed as representative of field conditions. For this scenario the model predicted that, under favorable oxygen conditions, $50 \%$ of an initial $0.2 \mathrm{mg} / 1$ xylene contamination level would still be present 2 years after the spill. Approximately 4 years would be required to completely degrade the xylene.

While the numbers obtained by the simple Monod model employed in the above example cannot be taken as accurate estimates of the disappearance of the target contaminants in any particular subsurface environment, the calculations clearly suggest that insufficiently large populations of active microbes may be a major contributing factor to the long periods frequently observed for clean-up of contaminated aquifer materials.

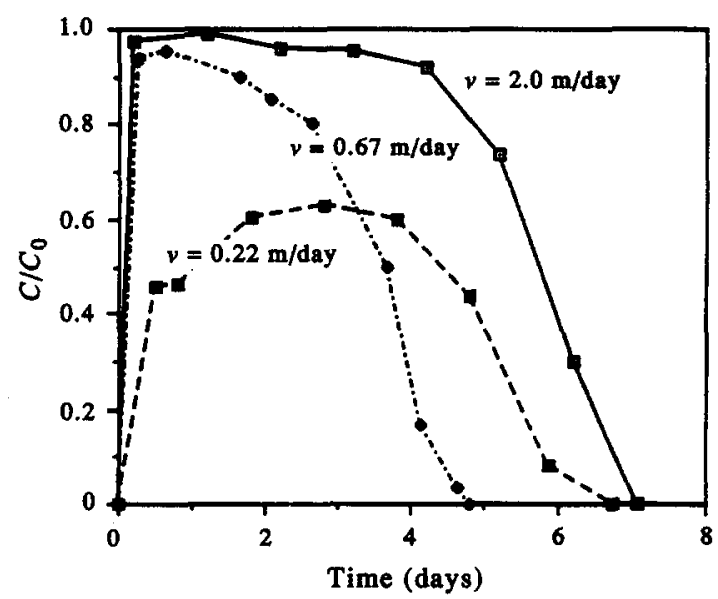

Fig. 11. $o$-Xylene breakthrough patterns $\left(C_{0}=25 \mu \mathrm{g} / \mathrm{l}\right)$ for different interstitial velocities.

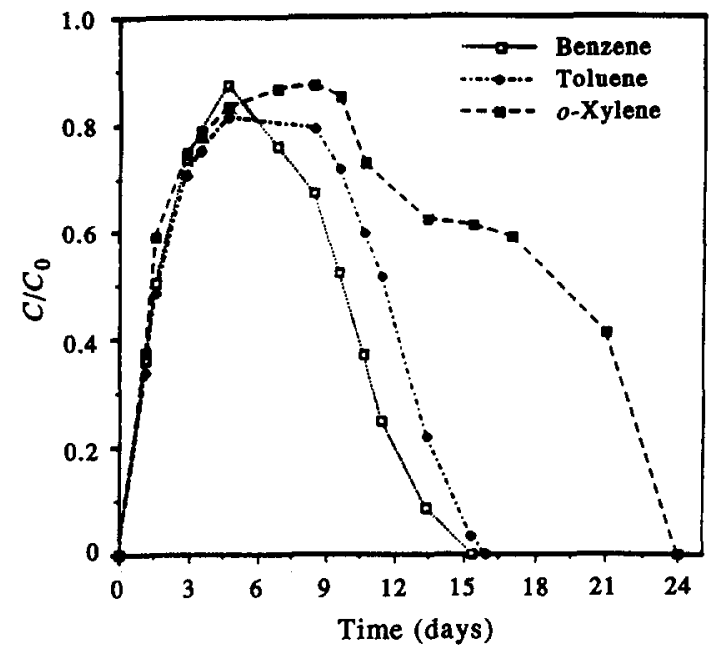

Fig. 12. Substrate breakthrough patterns for BTX compounds $\left(C_{0}=0.6 \mathrm{mg} / \mathrm{l}\right.$ for each compound $)$ in a mixed solution at $T=8^{\circ} \mathrm{C}$ and $v_{\mathrm{s}}=0.22 \mathrm{~m} /$ day.

\section{SUMMARY AND CONCLUSIONS}

The results of this study confirm that sufficiently large populations of indigenous organisms from perviously uncontaminated aquifer sands are able to degrade benzene, toluene and xylene in relatively short periods under favorable growth conditions and in the presence of adequate amounts of oxygen. The results also confirm, however, that the low populations of microbes typically present in subsurface systems may result in significant delays before onset of measurable biodegradation even under highly favorable oxygen and nutrient conditions. Such delays, referred to here as population development periods, were found to vary inversely with the number of contaminant-specific microorganisms initially present in indigenous consortia, suggesting the need for attainment of critical biomass concentrations. Although the latter finding is not particularly unexpected, it is seldom adequately addressed in applications of biotechnology for in situ subsurface remediation. Such applications generally focus on providing appropriate electron acceptor and nutrient conditions, and take development of sufficient microbial populations for granted. The results of this work suggest that this may not be appropriate practice, and that more attention should be given to the potential need for augmentation of indigenous microbial populations to ensure sufficiently high biomass concentrations for demonstrable rates of contaminant degradation (see, for example, Weber and Corseuil, 1994).

Acknowledgements - This work was supported in part by Research Grant 90-1112 from the Michigan Oil and Gas Association, Research Grant 5 P42 ES04911-03 from the National Institutes of Environmental and Health Sciences and by a Scholarship awarded to Mr Corseuil by CAPES, the Ministry of Education, Brazil. The work was performed at the University of Michigan. The authors thank Mark 
Henry and Angela Lee, graduate students in the Environmental and Water Resources Engineering Program at the University of Michigan at the time of this study, for their assistance in the experimental and analytical phases of the work. Dr Kevin P. Olmstead, a Postdoctoral Research Associate in the Program, provided helpful input to the experimental design of the work.

\section{REFERENCES}

Aamand J., Jørgensen C., Arvin E. and Jensen B. (1989) Microbial adaptation to degradation of hydrocarbons in polluted and unpolluted groundwater. J. Contam. Hydrol. 4, 299-312.

Aelion C. M., Swindoll C. M. and Pfaender F. K. (1987) Adaptation to and biodegradation of xenobiotic compounds by microbial communities from a pristine aquifer. Appl. Envir. Microbiol. 53, 2212-2217.

Alexander M. and Scow K. M. (1989) Kinetics of biodegradation in soil. In Reactions and Movement of Organic Chemicals in Soils (Edited by Swawney B. L. and Browns K.), Vol. 22, pp. 243-269. Soil Science Society of America.

APHA (1989) Standards Methods for the Examination of Water and Wastewater, 17th edition. American Public Health Association, Washington D.C.

Atlas R. M. and bartha R. (1987) Microbial Ecology Fundamentals and Applications, 2nd edition. Benjamin Cummings, Menlo Park, Calif.

Chang H. T. and Rittmann B. E. (1988) Comparative study of bioflim shear loss on different adsorptive media. J. Wat. Pollut. Control Fed. 60, 362-368.

Chiang C. Y., Salanitro J. P., Chai E. Y., Colthart J. D. and Kein C. L. (1989) Aerobic biodegradation of benzene, toluene and xylene in a sandy aquifer-data analysis and computer modeling. Ground Wat. 27, 823-834.

Corseuil X. C. (1992) Enhanced degradation of monoaromatic hydrocarbons in sandy aquifer materials of microbial inoculation using biologically active carbon reactors. Ph.D. dissertation, The University of Michigan, Ann Arbor, Mich.

Downey D. C. and Elliott M. G. (1990) Performance of selected in situ soil decontamination technologies: an air force perspective, Envir. Prog. 9, 169-173.

Focht D. D. and Shelton D. (1987) Growth kinetics of Pseudomonas alcaligenes $\mathrm{C}-\mathrm{O}$ relative to inoculation and 3-chlorobenzoate metabolism in soil. Appl. envir. Microbiol. 53, 1846-1849.

McCarty P. L. (1975) Stoichiometry of biological reactions. Prog. Wat. Technol. 7, 157.

McCarty P. L. (1985) Application of biological transformations in ground water. In Proceedings, Second International Conference on Groundwater Quality Research, Oklahoma State University, Stillwater, Okla.

McGinley P. M. (1991) Subsurface reactivity and its implication for the sorption and transport of hydrophobic organic compounds. Ph.D. dissertation, The University of Michigan, Ann Arbor, Mich.

Robertson B. R. and Button D. K. (1987) Toluene induction and uptake kinetics and their inclusion in the specific affinity relationship for describing rates of hydrocarbon metabolism. Appl. envir. Microbiol. 53, 2193-2205.

Robinson J. A. and Tiedje J. M. (1983) Nonlinear estimation of monod growth kinetic parameters from a single substrate depletion curve. Appl. envir. Microbiol. 45, 1453-1458.

Spain J. C., Prichard P. H. and Bourquin A. W. (1980) Effects of adaptation on biodegradation rates in sediment/water cores from estuarine and freshwater environments. Appl. envir. Microbiol. 40, 726-734.

Spain J. C. and Van Veld P. A. (1983) Adaptation of natural microbial communities to degradation of xenobiotic compounds: effects of concentration, exposure time, inoculum, and chemical structure. Appl. envir. Microbiol. 45, 428-435

Spain J. C. (1990) Microbial adaptation in aquatic ecosystems. In Enhanced Biodegradation of Pesticides in the Environment (Edited by Racke K. D. and Coats J. R.), Vol. 14, pp. 181-190. American Chemical Society.

Weber W. J. Jr and Corseuil H. X. (1994) Inoculation of contaminated subsurface soils with enriched indigenous microbes to enhance bioremediation rates. Wat. Res. $\mathbf{2 8 ,}$ $1407-1414$

Wiggins B. A., Jones S. H. and Alexander M. (1987) Explanation for the acclimation period preceding the mineralization of organic chemicals in aquatic environments. Appl. envir. Microbiol. 53, 791-795.

Wilson J. T., McNabb J. F., Balkwill D. L. and Ghiorse W. C. (1983) Enumeration and characterization of bacteria indigenous to a shallow water-table aquifer. Ground Wat. 21, 134-142. 